\title{
New Trends in Qualitative and Quantitative Methods in Libraries
}


This page intentionally left blank 

and Quantitative Methods in Libraries

Selected Papers Presented at the 2nd Qualitative and Quantitative Methods in Libraries

Proceedings of the International Conference on QQML2010 Chania, Crete, Greece 25-28 May 2010

Editors

Anthi Katsirikou

University of Piraeus Library, Greece

Christos Skiadas

Technical University of Crete, Greece 
Published by

World Scientific Publishing Co. Pte. Ltd.

5 Toh Tuck Link, Singapore 596224

USA office: 27 Warren Street, Suite 401-402, Hackensack, NJ 07601

UK office: 57 Shelton Street, Covent Garden, London WC2H 9HE

\section{British Library Cataloguing-in-Publication Data}

A catalogue record for this book is available from the British Library.

\section{NEW TRENDS IN QUALITATIVE AND QUANTITATIVE METHODS \\ IN LIBRARIES \\ Selected Papers Presented at the 2nd Qualitative and Quantitative Methods in Libraries \\ Proceedings of the International Conference on QQML2010}

Copyright (C) 2012 by World Scientific Publishing Co. Pte. Ltd.

All rights reserved. This book, or parts thereof, may not be reproduced in any form or by any means, electronic or mechanical, including photocopying, recording or any information storage and retrieval system now known or to be invented, without written permission from the Publisher.

For photocopying of material in this volume, please pay a copying fee through the Copyright Clearance Center, Inc., 222 Rosewood Drive, Danvers, MA 01923, USA. In this case permission to photocopy is not required from the publisher.

ISBN-13 978-981-4350-29-7

ISBN-10 981-4350-29-X

Printed in Singapore. 


\section{PREFACE}

The present volume contains selected papers of the $2^{\text {nd }}$ Qualitative and Quantitative Methods in Libraries International Conference (QQML2010) held in Chania, Crete, Greece, May 25-28, 2010, which was organized under the umbrella of ASMDA International Society.

The conference aims to serve the library community to familiarize Quantitative and Qualitative Methodologies and use them in the everyday management of the library. The conference also aims to serve the research community to present their papers and take the feedback from academia and professionals. As expected, the Conference, consequently its proceedings, is addressed to the library professionals in a more general sense: professors, researchers, students, administrators, librarians, technologists, museum scientists, archivists, decision makers and managers from 50 countries.

Qualitative and Quantitative Methods (QQM) have proved to be increasingly popular tools for library scientists, because of their usefulness to the everyday professional life. QQM are involved in the improvement of the services, the measurement of the functional effectiveness and efficiency, to decision-making and fund allocation.

This unique volume presents the last scientific achievements of library researchers and professionals on the Qualitative and Quantitative Methods of Libraries. Scholars and professionals have now an information resource on methodological tools for library services. Except of the new technologies that facilitate the innovation of libraries, it is the underlying policy and functional changes that have the most lasting effect on the scholarly operation. The book explores items such as library methodologies, marketing and management, statistics and bibliometrics, content and subject analysis, users' behaviours and library policies that play important role at every side of library research in the twenty-first century.

The contents cover issues such as Assessing and Evaluating Reference, Quantitative and Qualitative Methods in Library Marketing and Management, Using Qualitative and Quantitative Methods in Digital Library Education and Research, Library and Information Science and Research, Users and their Behaviours, Applications to Academic Libraries, Applications to Digital Libraries, Data Mining/Content Analysis, Information and Learning. 
Once more we would like to acknowledge the support of MAICh in Chania, Greece. Sincere thanks must be accorded to colleagues, friends and partners who have worked hard for the success of the conference and especially the conference committees, speakers and keynote speakers, authors and reviewers. Finally, we would like to heartily thank Aggeliki Oikonomou, Mary Karadima, Iro Tzorbatzaki, Aris Meletiou, Ioannis Dimotikallis and George Matalliotakis for their heartily envaluable support.

Athens, April 29, 2011

Anthi Katsirikou, University of Piraeus Library, Greece

Christos H. Skiadas, Technical University of Crete, Greece 


\section{ADVISORY COMMITTEE}

Prof. Carla Basili, National Council of Research, Italy

Prof. George Bokos, Ionian University, Greece

Dr. Judith Broady-Preston, Dep. of Information Studies, Aberystwyth University, UK

Dr. Colleen Cook, Texas A\&M University Libraries, USA

Prof. Peter Hernon, Simmons College, USA

Dr. Anthi Katsirikou, University of Piraeus Library, Greece

Dr. Martha Kyrillidou, Association of Research Libraries, Senior Director of ARL Statistics and Service Quality Programs, USA

Prof. Maria G. N. Musoke, Makerere University, Uganda

Prof. Lynne M. Rudasill, University of Illinois at Urbana-Champaign, USA

Prof. Christos Skiadas, Technical University of Crete, Greece

Dr. Bruce Thompson, Texas A\&M University, USA

Steve Thornton, Editor, Performance Measurement and Metrics, UK

Prof. Sirje Virkus, Tallinn University, Estonia

Prof. Teresa Welsh, The University of Southern Mississippi, USA

\section{INTERNATIONAL SCIENTIFIC COMMITTEE}

Svanhild Aabo (Oslo University College, Norway)

Melita Ambrozic (NUK Ljubliana, Slovenia)

Tatjana Aparac (University J.J. Strossmayer in Osijek, Croatia)

Agnes Hajdu Barat (University of Szeged, Association of Hungarian Librarians, Hungary)

Carla Basili (Consiglio Nazionale delle Ricerche, Istituto Ceris, Roma, Italy)

George Bokos (Ionian University, Greece)

Vesna Brujic-Okretic (City University, London, UK)

Stella Chatzemari (Technological Educational Institute, Greece)

Jenny Craven (CERLIM, Joint Editor LWW Conference Series)

Kathy Dempsey (Computers in Libraries, Editor, USA)

Corrado Di Tillio (Comune di Roma, Istituzione Biblioteche, Biblioteca Raffaello, Roma, Italy)

P. Dukic (Belgrade City Library, Serbia)

Blazej Feret (Technical University of Lodz, Library, Poland) 
Guisseppi A. Forgionne (University of Maryland, Editor-in-Chief Int. J. Decision Support Systems Technology, USA)

Norbert Fuhr (Dep. of Computational and Cognitive Sciences, University of Duisburg-Essen, Germany)

George Giannakopoulos (Library and Information Systems Dept., TEI of Athens, Greece)

Lindsay Glynn (Evidence Based Library and Information Practice Journal, University of Alberta, Canada)

Gary E. Gorman (Victoria University of Wellington, IFLA Advisory Board, Online Information Review, Editor, New Zealand)

Jillian Griffiths (CERLIM, Manchester Metropolitan University, UK)

Herbert Gruttemeier (INIST-CNRS, President, ICSTI, France)

Dinesh K. Gupta (Dept. of Lib. \& Inf. Sc., Vardhaman Mahaveer Open University, India)

Peter Hernon (Graduate School of Library and Information Science, Simmons College, USA, Co-Editor, Library and Information Science Research)

Frank Huysmans (University of Amsterdam, The Netherlands)

Jim Jansen (The Pennsylvania State University, USA)

Ian M. Johnson (Aberdeen Business School, The Robert Gordon University, UK)

Sarantos Kapidakis (Ionian University, Greece)

Sanjay Kataria (Jaypee Institute of Information Technology, India)

Anthi Katsirikou (University of Piraeus, Greece), Co-Chair

Christie Koontz (Florida State University, School of Library and Information, USA)

Marian Koren (Netherlands Public Library Association, Head of RIA, The Netherlands)

Steen Bille Larsen (The Royal Library, Denmark)

Jesus Lau (Universidad Veracruzana, Mexico)

Sue McKnight (Nottingham Trent University, Nottingham, UK)

Sona Makulova (Comenius University, Slovakia)

Paul Nieuwenhuysen (Vrije Universiteit Brussel, Belgium)

Nor Edzan Che Nasir (University of Malaya, Kuala Lumpur, Malaysia)

Steve O'Connor (The Hong Kong Polytechnic University, Editor, Library Management, Library Management, China) 
Aldo Pirola (Public Library System in Milan, Italian Librarian Association, EBLIDA, Italy)

Diana Pietruch-Reizes (The Polish Society of Information Science, Jagiellonian University, Poland)

Roswitha Poll (Munster University, Germany)

Niels Ole Pors (Royal School of Library and Information Science, Denmark)

Pirjo Rajakiili (National Library of Health Sciences, Finland)

Blanca Rodriguez Bravo (Universidad de Leon, Spain)

Ronald Rousseau (ISSI, Belgium)

Lynne M. Rudasill (University of Illinois at Urbana-Champaign, USA) Anabela Mesquita Teixeira Sarmento (ISCAP, School of Accountancy and Administration of Porto, Portugal)

Christos H. Skiadas (Technical University of Crete, Greece), Co-Chair Amanda Spink (Queensland University of Technology, Australia)

Gordana Stokic Simoncic (University of Beograd, Serbia)

Ruth Tammeorg (Tartu University Library, Estonia)

Rong Tang (Director, Simmons GSLIS Usability Lab, Graduate School of Library and Information Science, Simmons College, Boston, MA, USA)

Thordis T. Thorarinsdottir (Menntaskolinn vid Sund/University of Iceland)

Steve Thornton (Performance Measurement and Metrics, Editor, UK)

Sirje Virkus (Tallinn University, Estonia)

Sohair Wastawy (Dean of Libraries, Illinois State University, USA)

Sheila Webber (University of Sheffield, UK)

Aleksander Zgrzywa (Wroclaw University of Technology, Poland)

\section{ORGANIZING COMMITTEE}

Anthi Katsirikou,

Christos H. Skiadas,

Mary Karadima,

Aggeliki Oikonomou,

Iro Tzorbatzaki,

Aris Meletiou,

Ioannis Dimotikallis,

George Matalliotakis 


\section{KEYNOTE TALKS}

\section{Prof. Emeritus F. Wilfrid Lancaster: Fifty Years After - Almost.}

Graduate School of Library and information Science, University of Illinois at Urbana Champaign, Urbana, Illinois, USA. Short Biography. F. Wilfrid Lancaster is Professor Emeritus in the Graduate School of Library and Informotion Science at the University of Illinois where he has taught courses relating to information transfer, bibliometrics, bibliographic organization and the evaluation of library and information services. He served as the editor of Library Trends for a period of 20 years. He was appointed University Scholar for the period 1989-1992. He is the author of twelve books, six of which have received national awards, and has three times received Fulbright fellowships for research and teaching abroad. His books have been translated into Arabic, Russian, Chinese, Japanese, Korean, Spanish and Portuguese. From the American Society for Information Science and Technology he has received both the Award of Merit and the Outstanding Information Science Teacher award. Professor Lancaster has been invoved in a wide range of consulting activities, including service for UNESCO and other agencies of the United Nations.

\section{Dr. Roswitha Poll: Data for New Services: Developments in International Library Statistics.}

Former Chief Librarian, Mónster University Library, Germany. Short Biography. Dr. Roswitha Poll was chief librarian of Mónster University Library from 1987 to 2004. She is now chairing the committee "QualityStatistics and Performance Evaluation" and the working groups for "International library statistics", "Performance indicators for national libraries" and "Statistics for library buildings" within ISO (International Organization of Standardization). Since 1989, she has been working in IFLA (International Federation of Library Associations), especially in the section "Statistics and Evaluation". She works in projects dealing with management and evaluation of libraries and information systems. Her present publications deal with measures for the input and output, quality, costs and impact of library services.

\section{Prof. Carla Basili: Information Policies in the Knowledge Economy: A Question of Balance.}

National Council of Research, Italy. Short Biography. Carla Basili is Promoter and Co-ordinator of the European network on Information Literacy (EnIL) and of the European Observatory on Information Literacy Policies and Research. Her research interests focus on scientific information diffusion and transfer and, since 2001, concentrate on information literacy policies in higher education. 


\section{Contents}

Preface

\section{Selected Papers}

Fifty Years After - Almost

F. Wilfrid Lancaster

The New Challenges of the Statistic: Case UEF

Markku Laitinen and Aino Taskinen

Fractal Analysis of Knowledge Organization in Digital Library

Veslava Osinka

User's Perception and Satisfaction with Reference Services in

University Libraries of Punjab: A Survey

Shafiq Ur Rehman, Farzana Shafique and Khalid Mahmood

User Centred Libraries and Brand Name: The Case of Greek Public

Libraries

Anthi Katsirikou and Ageliki Oikonomou

Chapter 1. Assessing and Evaluating Reference: Views from the Academic Library Reference Desk

View from a Virtual Reference Desk

Lynne Rudasill

Using Data to Make Quick Decisions about a New Merged Service Desk: A Case Study

Elizabeth Cooper

Moving from Behind the Desk and into the Flow: Assessing the Impact of Research Support Activities

JoAnn Jacoby

One Librarian at a Time: Group Assessment via Self Assessment

Cynthia Johnson and Carol Ann Hughes

Access and Use of European Information: A Comparative Analysis

Ana Lúcia Terra 
Evaluation of Information Services in the Library: Areas Identified by Graduate Students

Naresh Kumar Agarwal

\section{Chapter 2. Quantitative and Qualitative Methods in Library Marketing and Management: A Practical Approach}

How to Teach Library Management

Angela Repanovici

Using Statistics - Quality Management in the Library

Ane Landøy

Greek Academic Repositories: Policies (?) for Making Available Scientific and Cultural Content

Manolis Koukourakis

Library Network Support Services: Quantitative and Qualitative Measures for Assessing the Impact of Information Literacy Initiatives on Learners

Jerald Cavanagh and Padraig Kirby

Electronic Academic Libraries Services Valuation: A Case Study of the Portuguese Electronic Scientific Information Consortium b-on.

Luiza Baptista Melo and Cesaltina Pires

The Use of Marketing Research Methods for the Evaluation of Information Literacy Services

Dionysis Kokkinos, Eleni Papadatou and Nina Sisamaki

Development of Management Methods in Polish Libraries and Information Centers. Hitherto Existing Solutions, New Trends and Directions of Research

Maja Wojciechowska

\section{Chapter 3. Using Qualitative and Quantitative Methods in Digital Library Education and Research}

The Use of Phenomenographic Approach to Investigate Students' Conceptions of the Use of Web 2.0 Tools

Alice Adejoke Bamigbola

Application of Preservation Metadata for Long-Term Accessibility of Digital Objects

Yibeltal Tafere Bayih 
Exploring User's Information Behavior in Social Networks

Juan Daniel Machin Mastromatteo

Using Qualitative Case Study Methodology to Assess Information Access Needs and Open Educational Resources (OER) Awareness among Faculty and Students of MOI University, Nairobi Campus - Kenya

Monica Wawira Gakindi

A Mixed Model Study to Determine User Preferences for Delivery of Collection Content via Mobile Devices: Lessons for the Development of a Smartphone Application

Sara Grimm

Data Collection Process and Technique to Determine the Image Characteristics of Photogrammetry in Cultural Heritage Domain Mehrnoosh Vahdat

\section{Chapter 4. Library and Information Science Post-Graduate Student Research}

Documentation of Library Compliance in Regional Accreditation Standards: A Survey of Accreditation Liaisons and Librarians of Level-One Institutions of the Southern Association of Colleges and Schools

Donna S. Ballard

Publishing Patterns and Authorship in the Scholarly Literature of Digital Object Identifiers: A Bibliometric Analysis

Donna S. Ballard

Characters of Color. A Content Analysis of Picture Books in a Virgin Islands Elementary School Library

Marilyn M. Brissett

Anthropological Literature on Social Phobia: An Examination of Publishing and Indexing Patterns

Julie D. Shedd

Educational Choices and Learning Careers of LIS Students as a Social Process: Theoretical and Methodological Considerations

Valentini Moniarou-Papaconstantinou and Anna Tsatsaroni 


\section{Chapter 5. Users and Their Behaviours}

Using Qualitative Approach for a Psychographic Segmentation of the Users of Library Services

Chiara Faggiolani

Do We Know Image Users?

Marija Petek

Psychometric Properties of the Computer and Web Attitude Scale (CWAS): An Application to Greek Library Students

Aspasia Togia, Afrodite Malliari, Stella Korobili and

Nikolaos Tsigilis

Generational Technology Expectations of Library Users:

A Case Study

Rachel Williams and Jennifer Cromer

User Preferences for Virtual Information Retrieval:

A Qualitative Study

Alan MacLennan

Matching the Databases' User Interface with Ellis' Model of Information Seeking Behavior: A Qualitative Survey

Mohammad Azami and Rahmattolah Fattahi

Exploring the Research Knowledge Needs of Canadian

Academic Librarians

Alvin M. Schrader

\section{Chapter 6. Academic Libraries}

UCSC Nexus Project: Fostering Networking between Academic Scholars and Library Staff. Qualitative Methods for Assessing Perceived Value of Library Services

Liliana Gregori, Luca Losito and Paolo Sirito

Research Library Statistics: For Whom and for What Purpose?

The Statistics Users' Views and Wishes

Cecilia Bodelsson, Catarina Jacobsson and Tore Torngren

Performance Appraisal of Library Staff Working in Turkish Universities

Leyla Kanik 
Automated Metadata Harvesting Among Greek Repositories in the Framework of EuropeanaLocal: Dealing with Interoperability

Alexandros Koulouris, Emmanouel Garoufallou and

Evangelos Banos

The Benefits of a Quality Management System - The Case of the Merger of Two Universities and Their Libraries

Jarmo Saarti and Arja Juntunen

\section{Chapter 7. Digital Libraries}

Paving the Way for Interoperability in Digital Libraries:

The DL.org Project

Katerina El Raheb, George Athanasopoulos, Leornardo

Candela, Donatella Castelli, Perla Innocenti, Yannis Ioannidis, Akrivi Katifori, Anna Nika, Stephanie Parker, Seamus Ross, Costantino Thanos, Eleni Toli, and Giuseppina Vullo

Squaring the Circle: A Comparative Perspective on Digital Library Evaluation Models

Giuseppina Vullo

Digital Libraries and the Digital Working Environment: What is Their Effect on Library Staff for Sharing Their Knowledge?

Garoufallou Emmanouel and Asderi Stella

Case Study Method for Research on Digital Library, Information Policies, and Bibliographic Organization

Georgina Araceli Torres-Vargas, Ariel Alejandro

Rodríguez-García and Egbert John Sánchez-Vanderkast

Experimental Workflow Development in Digitisation

Mustafa Dogan, Clemens Neudecker, Sven Schlarb and

Gerd Zechmeister

\section{Chapter 8. Library Applications and Methodologies}

Co-Word Analysis of Doctoral Dissertations in Information

Science in the Republic of Croatia from 1978 to 2007:

Contribution to Research of Development of Information Science

Miroslav Tuđman and Đilda Pečarić

Satisfaction and Relevance of Libraries and Technology in

Ukraine and Romania

Svetlana Kolesnik and Katie Sheketoff 
Library Performance Management in Rio de Janeiro, Brazil:

Applying DEA to a Sample of University Libraries in 2006-2007

Frederico A. de Carvalho, Marcelino José Jorge,

Marina Filgueiras Jorge, Mariza Russo and

Nysia Oliveira de Sá

Grounded Analysis of the Use of Public Libraries in Appalachia by Non-Residents

Sheri Ross

Supporting PDF Accessibility Evaluation: Early Results from the FixRep Project

Andrew Hewson and Emma Tonkin

Heuristics for the Evaluation of Library Online Catalogues

Thomas Weinhold, Sonja Oettl and Bernard Bekavac

The Next Generation of OPACs: What do Experts Consider as Musts and Don'ts?

René Schneider

\section{Chapter 9. Information and Learning}

Books Circulation and Teaching Support: A Case Study in a Nutrition-Dietetics Department Library

Maria Kampouraki, Nikos Thalassinos and Georgios

A. Fragkiadakis

Electronic Scholarly Communication, Availability, Utilization and its Imperatives to Academic Libraries in Nigeria

Scholoastica A. C. Ukwoma, Victoria N. Okafor and

Ifeoma Udeh

Author Index

Title Index 